\title{
Do Digital Public Services Matter? A Comparative Study of the Czech Republic and the Republic of Kazakhstan
}

\author{
M. Ulman ${ }^{1}$, N. S. Ualiyev², M. B. Toregozhina ${ }^{3}$ \\ ${ }^{1}$ Faculty of Economics and Management, Czech University of Life Sciences Prague, Czech Republic \\ ${ }^{2}$ Centre for the Development of Information Systems and Electronic Administration, Zhetysu State \\ University named after I.Zhansugurov, Taldykorgan, Kazakhstan \\ ${ }^{3}$ Faculty of Economics and Finance, Zhetysu State University named after I.Zhansugurov, Taldykorgan, \\ Kazakhstan
}

\begin{abstract}
Provision of quality public services has been in great concern of many governments for longer period of time. An interesting fact could be observed that, as to the demand and supply of digital public services, some developed European countries could lag behind some upper-middle-income countries. The paper explores differences in digital public services provision (supply side) and use (demand side) between the Czech Republic and Kazakhstan. A document analysis was done and a comparative study based on secondary data was elaborated. We can confirm that even a country from outside of the EU (Kazakhstan) can provide a better organized supply of digital services than an EU member state (Czech Republic) at least on the national level. According to the Digital Economy and Society Index (DESI) benchmarking, there are also significant discrepancies among national, regional and local services in the EU. The same phenomenon is also reported from transitional countries like Kazakhstan.
\end{abstract}

\section{Keywords}

Digital public services, electronic public services, rural development, e-government, European Union, DESI, EGDI, Czech Republic, Kazakhstan.

Ulman, M., Ualiyev, N. S. and Toregozhina, M. B. (2016) "Do Digital Public Services Matter? A Comparative Study of the Czech Republic and the Republic of Kazakhstan", AGRIS on-line Papers in Economics and Informatics, Vol. 8, No. 2, pp. 121-133. ISSN 1804-1930. DOI: 10.7160/aol.2016.080210.

\section{Introduction}

Provision of digital services from government to citizens and businesses has evolved during past 25 years. From setting up a website and publishing basic contact information online in early 1990s, through electronic forms to download, to sophisticated web and mobile applications that enable us to fill in a tax return and pay at the same browser window.

Digital public services or e-government services refer to electronic services provided by a municipality or by central government. Example of a local (municipality) service could be ordering and renewing waste collection, while a central government service could be e.g. applying for new ID card. Some services are used on regular basis (e.g. change of the employer at the social insurance administration), while some other services are used sporadically (e.g. paying parking fine).

According to (Lindgren and Jansson, 2013), a public electronic service is in part a process creating value for someone else (e.g. citizen, business, etc.) and an IT artifact that mediates the public service. Regarding the fact that electronic public services have direct impact on citizens, businesses and even government, EU has laid out twelve principles for implementation of these services (EC, 2010). On the other hand, it is up to the Member States which principles will be deployed and preferred (Limba and Gulevičiūtè, 2013). Even if academics and practitioners urge to prescribe design specifications for the development of user-centric and quality-driven e-government websites, the consensus is missing (Tan, Benbasat, and Cenfetelli, 2013). However, public service provision today should not be only about a series 
of transactional services but more about an integrated set of services organized around the life event of the user (EC, 2014).

Citizens and businesses expect quality public services, including electronic public services. Higher satisfaction of online service users can be achieved by development of strategies for services improvement, analysis of quality and definition of accountability (Sá, Rocha and Pérez Cota, 2015). A survey in China showed that perceived quality of offline and online services has a high impact on overall public satisfaction with electronic government services (Fan and Yang, 2015). Ease of use, trust and public value belong among factors affecting citizens' attitudes toward electronic public services (Al-Hujran, Migdadi, Al-Debei and Chatfield, 2015).

In general, electronic government services are much likely used by enterprises than by citizens from the long-term perspective. In 2013 in the EU, there were $88 \%$ of enterprises that used the Internet to interact with public administration while only $46 \%$ of the EU-28 citizens used e-government services in 2015. The interactions include: obtaining information or forms from websites, returning filled in forms, following administrative procedures completely electronically or offering products in public authorities' electronic procurement systems (eTendering) (Eurostat, 2014). Though, there is limited empirical research of e-government for businesses (Reddick and Roy, 2013; Skersys et al., 2011). For example, in Netherlands, companies reported at least a partial reduction of administrative burden in less than half of observations, which opposes usual claims about contributions of e-government for companies (Arendsen, Peters, ter Hedde, and van Dijk, 2014). Reporting and other information requirements of administration, taxes, social insurance, various requests for permission, subsidies and grant funding belong to most frequent duties toward government. Evaluation of e-government effects on companies has not brought sufficient evidence (Arendsen et al., 2014; Jones, Irani and Sharif, 2007; Kunstelj and Vintar, 2004), or includes a limited rehearsal and quantification of factors influencing satisfaction of enterprises with electronic public services (Reddick and Roy, 2013).

\section{ICT and rural development}

Information and communication technologies greatly impact inhabitants and their quality of life in rural areas. Effective use of ICT can remove geographical boundaries and bring rural communities closer to global economic systems (Nayak, 2010). Geographically, rural areas are more difficult to service with roll-out of fibre optic cable (Townsend, 2013) and sometimes even with wireless broadband Internet. Moreover, people in rural and urban areas have different attitudes toward technologies (Gilbert et al, 2010).

In Europe, connectivity and use of Internet are monitored within Digital Agenda for Europe 2020 policy. As of 2015, $97 \%$ of European households had access to fixed line broadband connection (at least $30 \mathrm{Mbps}$ ) and $79 \%$ to mobile 4G LTE Internet. However, rural coverage remains significantly lower (EC, 2015).

Much more remarkable differences could be observed especially in geographically large countries such as China where the gap between rural and urban areas is astoundingly huge (Lijuan et al, 2014). An institutionalized program called "Village Informatization Program" (VIP) was introduced in China to provide a single platform for inhabitants in rural areas for access to communication infrastructure and applications of "comprehensive information services". The VIP program is an unique approach to e-government (Xia, 2010).

Further, in Iran where some rural areas are affected with high poverty, people are excluded from new technologies such as ICT. Therefore, the implementation of tangible outcomes of development policies such as ICT centers may help to adopt new technology despite economic background of people (Khalil Moghaddam and Khatoon-Abadi, 2013).

Australia's rural areas where lives about $30 \%$ of population continue to be at a digital disadvantage. For example, Australian farming community needs government extension services targeted for farmers, extension professionals (consultants) and managers (Miah, 2012).

\section{Global benchmarks to measure e-government and information society}

Interaction of businesses and citizens with the public sector has become a priority for many national governments and also at international level such as in the European Union. The Digital Economy and Society Index (DESI) has become a high-level tool to measure and track progress of EU countries towards a digital economy and society (EC, 2016a; Sorrentino, De Marco and Depaoli, 2015). 
DESI is a composite index that summarizes some 30 relevant indicators on Europe's digital performance and tracks the evolution of EU Member States, across five main dimensions: Connectivity, Human Capital, Use of Internet, Integration of Digital Technology, Digital Public Services. Each dimension is divided in a set of sub-dimensions, which are in turn composed by individual indicators (as depicted on Figure 1). Each dimension has its weight in overall score. The weights reflect the EU's digital policy priorities (EC, 2016a).

\begin{tabular}{|l|c|}
\hline Dimension & Weight \\
\hline 1 Connectivity & $25 \%$ \\
\hline 2 Human Capital & $25 \%$ \\
\hline 3 Use of Internet & $15 \%$ \\
\hline 4 Integration of Digital Technology & $20 \%$ \\
\hline 5 Digital Public Services & $15 \%$ \\
\hline
\end{tabular}

Source: (EC, 2016a)

Table 1: DESI weights of dimension.

United Nation's Department of Economic and Social Affairs (UNDESA) has been monitoring e-government globally on biannual basis since 2003. UN uses E-government Development Index (EGDI) that comprises three normalized scores: Online Service Index, Telecommunication Infrastructure Index and Human Capital Index, where all of them have a fair weight (one third). Online Service Index (OSI) is described as follows: "OSI is calculated from data provided by each country's national website assessment, including the national portal, e-services portal and e-participation portal, as well as the websites of the related ministries of education, labour, social services, health, finance and environment as applicable. The e-participation index (EPI) is derived as a supplementary index to the UN's E-government Survey. It extends the dimension of the survey by focusing on the use of online services to facilitate provision of information by governments to citizens ("e-information sharing"), interaction with stakeholders ("e-consultation") and engagement in decisionmaking processes ("e-decision making")" (UN, 2014).

The level of government's performance in delivering online services to the citizens is categorized into four stages of service delivery: Emerging, Enhanced, Transactional, and Connected. Online services are assigned to each stage according to their degree of sophistication, from the more basic to the more sophisticated. In each country, the performance of the government in each of the four stages is measured as the number of services provided as a percentage of the maximum services in the corresponding stage. Examples of services include online presence, deployment of multimedia content, governments' solicitation of citizen input, widespread data sharing, and use of social networking (UN, 2014).

However, some countries argue that the UN survey either does not capture their latest innovations or does not provide enough guidance to be useful in practice. The survey seeks to capture the amount of services offered, but for example in Denmark there are currently fewer services offered than before. Denmark has automated its tax filing process, which means there is no longer a need to file taxes, online or offline. Another difficulty is assessing qualitative differences between similar services. For instance, UK spent billions on failed e-health records, whereas Estonia has a very successful system in place, yet the UK ranks well ahead of Estonia in the UN survey (EIU, 2013).

As the UN specialized agency for ICTs, International Telecommunication Union (ITU) is the official source for global ICT statistics. ITU uses the ICT Development Index (IDI) that combines 11 indicators to monitor and compare developments in ICT between countries and over time since 2009. IDI focuses also on the digital divide and the development potential of ICTs. The IDI is divided into the following three sub-indices: Access sub-index (40\%), Use sub-index (40\%) and Skills sub-index (20\%) (ITU, 2015).

EGDI is based on a survey questionnaire to tick off whether particular features are present or not. This approach removes any qualitative judgments about each feature, but it also limits the survey to a set of binary questions. EGDI does not provide the information to what extent digital services are easy to use or how they differ in terms of quality (EIU, 2013). EGDI is also used by OECD as a basis for calculation of E-government Readiness Index that measures government's capacity to use ICT-enabled public administrations and to develop and implement e-government services, scale from 0 (low) to 1 (high) (OECD, 2014). Unlike DESI, EGDI and EPI do not consider particular interactions regarding life events of citizens and businesses.

World Economic Forum (WEF) has been providing the Global Information Technology Report since 2002. In the report, the Network Readiness Index 
(NRI) is used to measure the "degree to which a community is prepared to participate in the Networked World" and to estimate a community's potential to participate in the Networked World in the future (Kirkman, Cornelius, Sachs, Schwab and World Economic, 2002). The report presents assessment of countries' capacity to exploit ICT. The Network Readiness Index (NRI) comprises 53 individual indicators distributed across four pillars such as Environment, Readiness, Usage and Impact subindexes. There is Government usage under Usage pillar that also regards availability and quality of government online services. Actually, WEF's benchmark draws on UN's Government Online Service Index data (WEF, 2015).

\begin{tabular}{|l|c|c|c|}
\hline & DESI & EGDI & NRI \\
\hline Started since & 2012 & 2001 & 2002 \\
\hline No. of sub-indexes / dimensions & 5 & 4 & 4 \\
\hline No. of indicators / components & 30 & 18 & 53 \\
\hline Digital public services & yes & yes & yes \\
\hline
\end{tabular}

Source: compiled from (EC, 2016; UN, 2014; WEF, 2015) Table 2: Comparison of DESI, EGDI and NRI.

Ardielli and Halásková (2015) argue that e-government data of international organizations are not consistent with each other due to different time periods, methodologies of data collecting and processing and various focus of e-government services. For comparative purposes, synthetic approaches such as methods of multi-criteria evaluation of alternatives (Ardielli and Halásková, 2015) or multiple criteria decision making methods (Máchová, 2015) should be used. Moreover, current benchmarking and ranking tools do not differentiate between static websites and highly integrated and interactive portals (Rorissa, Demissie and Pardo, 2011).

The attempt to make an international comparison of digital society indicators between the EU and 15 other developed countries was introduced in the International DESI (I-DESI)(Mateus, 2016). I-DESI shows that the top EU countries such as Denmark, Sweden and Finland are also top worldwide performers in digital. There are some differences in data collection and definition since scores and rankings of EU countries in DESI are not the same in I-DESI. However, the European countries need to significantly improve in order to catch up with its best performers as well as with the most digitized countries in the world (Japan, South Korea and the USA) that have all scores above the EU average (Burden, 2016; Mateus, 2016).

After reviewing main global benchmarking tools above, an interesting fact could be observed that, as to the demand and supply of digital public services, some developed European countries such as Czech Republic could lag behind some upper-middleincome countries such as Kazakhstan. The main aim of the paper is to explore differences in digital public services provision (supply side) and use (demand side) between two countries - the Czech Republic and Kazakhstan.

\section{Materials and methods}

In this study, a document analysis was conducted to understand current state of digital public services in the Czech Republic and the Republic of Kazakhstan. Research includes a thorough review of texts and documents such as: government publications, international reports, official statistical resources and scientific papers.

The comparative study was made between the Czech Republic and the Republic of Kazakhstan on the basis of the UN's E-government Survey 2014, WEF's The Global Information Technology Report 2015, OECD's Science, Technology and Industry Outlook 2014 and ITU's Measuring the Information Society Report 2015.

In the study, following research questions were addressed.

Research Question 1: What are differences in digital public services supply and demand among an EU and non-EU country?

Research Question 2: Are there available comparable data about the use and quality of digital public services at national and local level among an EU and a non-EU country?

\section{Results and discussion}

For the sake of comparison, some background data about both countries should be considered. In the Table 3, basic economy characteristics and number of Internet users are presented.

In DESI 2016, the Czech Republic has an overall score of 0.5 and ranks 17 th out of the $28 \mathrm{EU}$ Member States. A brief assessment of the Czech digital landscape shows that there is a good take-up of fast broadband and mobile broadband, which goes hand in hand with a decent level 


\begin{tabular}{|l|c|c|c|c|c|c|}
\hline & $\begin{array}{c}\text { Population } \\
\text { (in millions) }\end{array}$ & $\begin{array}{c}\text { Size } \\
\text { (in sq km) }\end{array}$ & $\begin{array}{c}\text { GDP } \\
\text { (in bln. USD, 2015) }\end{array}$ & $\begin{array}{c}\text { GDP per capita } \\
\text { (in USD, 2015) }\end{array}$ & $\begin{array}{c}\text { Income } \\
\text { (World Bank, } \\
\text { 2016a) }\end{array}$ & $\begin{array}{c}\text { Internet users } \\
\text { (\% of population, } \\
\text { ITU, 2014) }\end{array}$ \\
\hline Czech Republic & 10.6 & 78,867 & $\$ 331.4$ & $\$ 31,480$ & High-income & $79.7 \% *$ \\
\hline Kazakhstan & 18.1 & $2,724,900$ & $\$ 430.5$ & $\$ 24,345$ & $\begin{array}{c}\text { Upper-middle- } \\
\text { income }\end{array}$ & $54.9 \%$ \\
\hline
\end{tabular}

Note: * population of age 16-74

Source: compiled from (World Bank, 2016a; CIA, 2016; IMF, 2015; ITU, 2015)

Table 3: Czech Republic and Kazakhstan - basic characteristics.

of digital skills and engagement of Czech citizens in a variety of online activities. Czech internet users excel in online banking and in online shopping. In Czech private sector, digital technologies are used both to improve efficiency and productivity of companies as well as to access wider markets and help to lead the ranks in turnover from online sales. Moreover, the Czech Republic is below average in the provision of digital public services, which is its main challenge to progress further in the digital economy. The country falls into the cluster of falling behind countries (such as Bulgaria, Greece, France, Hungary, Poland and Slovakia) whose score is below the EU average and which grew slower than the rest of the EU since 2015 (EC, 2016a).

Kazakhstan e-government evaluation is not included in DESI, nor in International DESI, which compares EU member states with several world leading digital countries outside of the EU. According to the UN, Kazakhstan has kept its leading position in e-government in Central Asia region and is the only country in Central Asia to show improvements between 2012 and 2014, jumping from a global ranking of 38 th in 2012 , to $28^{\text {th }}$ in 2014. The decline in global ranking has been a trend in the region with the exception of Kazakhstan since 2008. UN argues that it could be attributed to insufficient development of telecommunication infrastructure and online presence. Kazakhstan is also between 50 top performers in e-participation. (UN, 2014).

A direct comparison of government online services is available only in the UN survey where the Government Online Service Index ranked the Czech Republic on 84th position and Kazakhstan on $23 \mathrm{rd}$ position.

A summarized view on the e-government in both countries according to the global surveys referenced above is presented in further text.

\section{Czech Republic e-government ranking}

According to the executives' opinion survey conducted by the WEF in 2013 and 2014, the Czech Republic ranked $116^{\text {th }}$ in importance of ICTs to government vision of the future which denotes to what extent does the government have a clear implementation plan for utilizing ICTs to improve the country's overall competitiveness, $84^{\text {th }}$ in Government Online Service Index, $56^{\text {th }}$ in impact of ICTs on access to basic services which means to what extent do ICTs enable access for all citizens to basic services (e.g., health, education, financial services, etc.), and $116^{\text {th }}$ in government success in ICT promotion which measures how successful is the government in promoting the use of information and communication technologies (ICTs) (WEF, 2015).

Among selected economies of Eastern Europe, Hungary, Russian Federation, Czech Republic and Poland are far in advance of provision of online services to disadvantaged and vulnerable groups as compared to Belarus and Ukraine (UN, 2014).

\section{Digital public services in the Czech Republic}

To obtain a richer picture of provided digital public services in the Czech Republic, we can use recent Digital Economy and Society Index (DESI) benchmark. The benchmark was firstly conducted in 2012 for three various life events and their related services. In 2013, other four life events were examined and assessed in the EU member states. Among the life events assessed in 2013 belong:

- Regular business operations;

- Moving (general administration);

- Owning and driving a car;

- $\quad$ Starting a small claims procedure.

In the Table 5 below, a list of related online services is presented. Every life event was assessed by two 


\begin{tabular}{|l|l|l|}
\hline Life event & Service labels & \multicolumn{1}{|c|}{ Location } \\
\hline \multirow{5}{*}{ Regular business operation } & $\begin{array}{l}\text { Obtain information on employee contractual agreements / regulation } \\
\text { Requesting a refund of VAT } \\
\text { Possibilities for objection and appeal against a claiming refund of VAT } \\
\text { decision }\end{array}$ & National \\
\hline & $\begin{array}{l}\text { Obtain information on related legislation and rights } \\
\text { Start a small claim procedure (issue the money claim at court) } \\
\text { Share evidence/supporting documents by citizen } \\
\text { Obtain information on case handling } \\
\text { Retrieve judgement } \\
\text { Appeal against court decision } \\
\text { Obtain information on how to start a civil/small claim procedure }\end{array}$ & \multirow{2}{*}{ Regional/National } \\
\hline Moving (general administration) & $\begin{array}{l}\text { Obtain information on local facilities (e.g. schools, sports, health } \\
\text { facilities) } \\
\text { Obtain permits for moving } \\
\text { Obtain information on rights and obligations when moving abroad } \\
\text { Issue a registration certificate }\end{array}$ & \\
\hline Owning and driving a car & Dealing with driving fines & Local \\
\hline
\end{tabular}

Source: compiled from eGovernment raw data (EC, 2014)

Table 5: Czech Republic - assessment of four life events and background digital services.

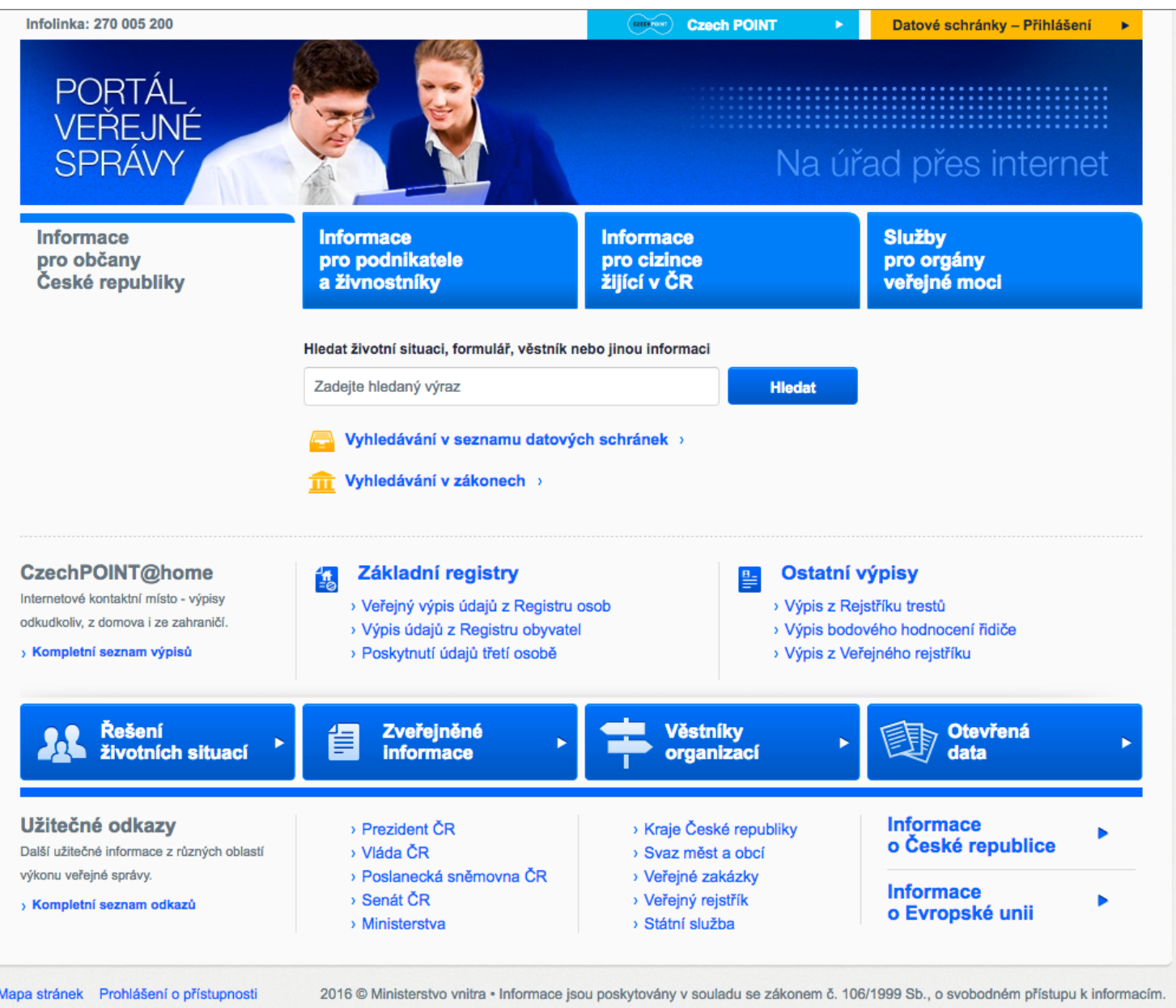

Source: http://portal.gov.cz

Figure 1: Portal of public administration in the Czech Republic. 
mystery shoppers who followed given scenario with tasks. Since the evaluators were not coming from the country, they had to work with information provided in English, which was often lacking or insufficient. The benchmark is quite robust because the assessed services were examined on all levels - national, regional and local.

Czech citizens have greatly adopted e-services such as e-banking and Internet. The Czech Republic is also on the top position in the number of e-shops per capita in the Europe. However, the overall supply of e-government and online public services have not been viewed positively (EC, 2016b).

Governments are aware of making their online services user-friendly. But, their focus is still mostly on making services available, they are lagging behind in improvement of services speed, ease of use, and transparency (EC, 2016a), which is also the case of the Czech Republic (EC, 2014).

A notable fact is that as of 2016 in the Czech Republic there is no national government portal that would provide all digital public services on one place. Instead, all national services are scattered on websites of various ministries or central government authorities such as the Czech Social Security Administration and other. The portal of public administration www.portal.gov.cz serves as a mere directory with prevailing text information about life events and links to respective authorities or forms. The portal operates only in Czech language and provides a simple hotline support (see Figure 1).

Digital public services in rural areas in the Czech Republic

The Czech Republic has a decentralised administration with 13 regions and 6,249 municipalities including the capital Prague (Czech Statistical Office, 2013). More than $73 \%$ of population lives in urban areas. There is a legal requirement that each municipality has to publish basic information online such as the representatives' names, working hours, contact details, minutes from representative meetings and municipality budget. However, further electronic services are optional and depend on decisions of the municipality management. A detailed evaluation of Czech municipality websites was conducted in June 2015 with the use of Citizen Web Empowerment Index (CWEI) introduced by UN (Ntaliani et al., 2015; UN, 2014). The issues of digital divide and deficiency of fast Internet access are still echoing in the Czech Republic namely in rural areas as was pointed out in (Vanek, Cervenkova, Jarolimek and Simek, 2010).

The main point of contact with government services is through the network of assisted places called Czech POINT that was started in 2007. The network currently operates at more than 7170 places all over the Czech Republic. More than $79 \%$ of branches are placed at municipality offices and $14 \%$ at Czech Post offices. Among the most used documents that could be obtained from $\mathrm{Czech}$ POINT belong verified copies from the Cadastre of Real Estate, the Companies Register, the Trade Licensing Register and the Criminal Record Register (MOIA, 2016).

\section{Kazakhstan e-government ranking}

In the WEF survey, Kazakhstan ranked $43^{\text {rd }}$ in importance of ICTs to government vision of the future, $23^{\text {rd }}$ in Government Online Service Index, $62^{\text {nd }}$ in impact of ICTs on access to basic services and $24^{\text {th }}$ in government success in ICT promotion (WEF, 2015).

Kazakhstan is 2nd among middle income countries in online service delivery and $23^{\text {rd }}$ globally. The country belongs to 11 upper-middle income countries and 36 high income countries providing online services for older persons. Kazakhstan has also ranked among countries with score higher than $66.6 \%$ in whole government and in data publishing (UN, 2014).

Both the Czech Republic and Kazakhstan are one of those putting out information and services for the immigrants. Kazakhstan also provides online services for women (UN, 2014).

\section{Digital public services in Kazakhstan}

Kazakhstan is a very large country with size equal to the Western Europe. Kazakhstan is facing much more diverse socio-economic and technological conditions than many successful e-government countries with relatively small territorial entities such as Baltic states or the Czech Republic. There are also significant variations in Internet availability, usage, affordability and reliability between large cities and rural areas (Janenova, 2010).

All central digital public services are provided at the national portal egov.kz (see Figure 2). Currently, there are more than 100 services at different stages of delivery supporting various life events of citizensand businesses. As of 2016, there were 17 digital services available 
through mobile application and 2 services via SMS service. The portal operates in three languages - Kazakh, Russian and English. Most of information, news, guidelines and even education videos on the portal operate in all three languages, which is very remarkable. Portal users can also interact with provider via free hotline support, feedback form, and polls. There are also large frequently asked questions and knowledge base sections.

Digital services that enable electronic submission require to have a valid electronic digital signature (EDS) which can be obtained on chip ID card or as a file on PC. Currently, more than 3.5 million users at the national portal E-gov.kz has received EDS (Interfax, 2015). Certificates for EDS are issued for free.
Kazakhstan is also ranked well in conditions for starting and operating business. According to the latest Doing Business 2016 report from the World Bank, Kazakhstan ranked $41^{\text {st }}$ globally (World Bank, 2016b). Kazakhstani government attributes electronic services the ability to establish good environment for business. For example, registering a new private limited liability company requires only 2 days in Kazakhstan including all administrative steps such as issuance of the electronic certificate and the certificate of state registration of a company. The registration of small or middle-sized company is free of charge as of $1^{\text {st }}$ January 2015 (World Bank, 2016b).

It also has to be noted that the above presented digital services are available in Kazakhstan on the national level. More detailed data about evaluation of digital services at regional or local

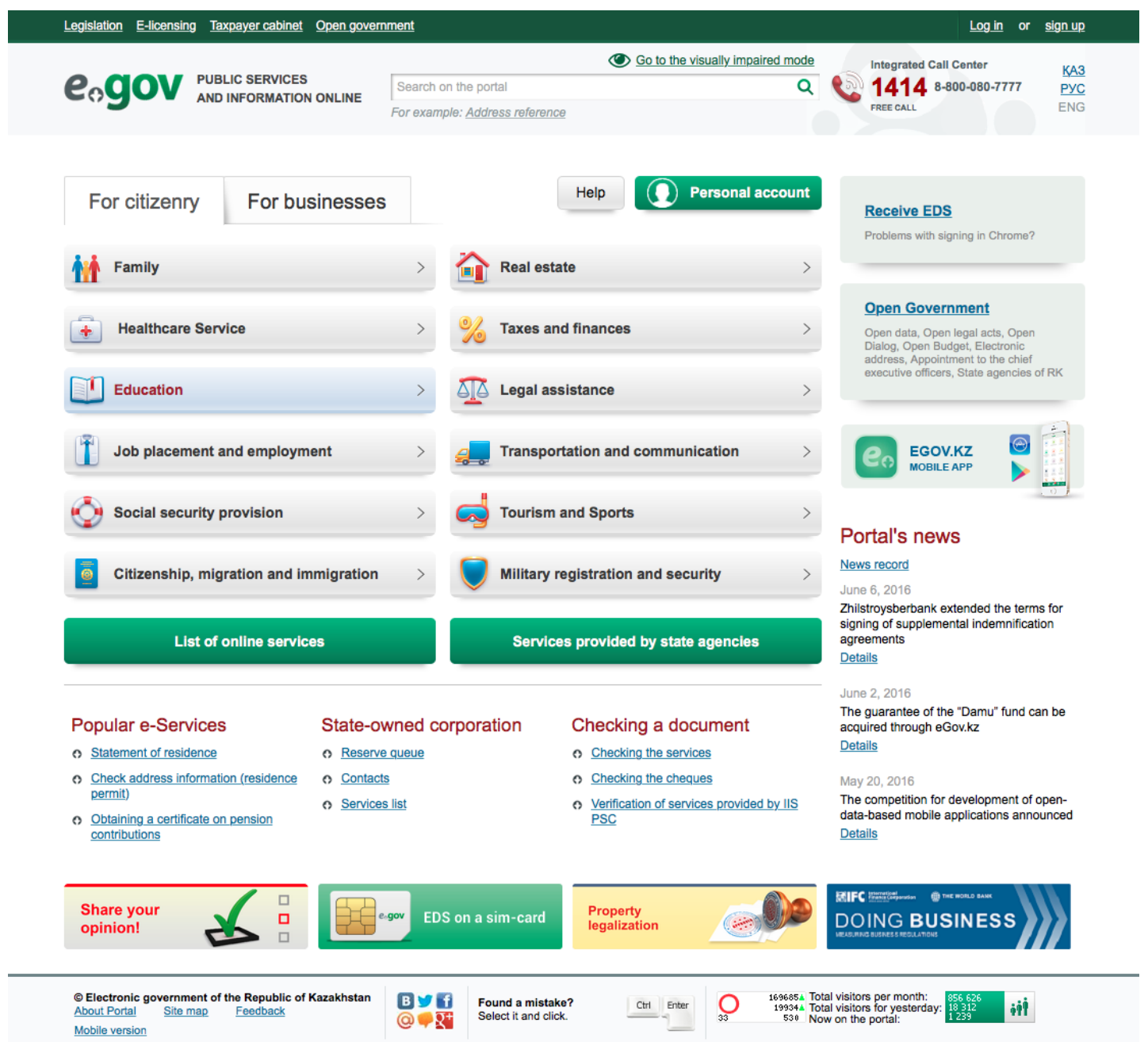

Source: http://egov.kz

Figure 2: Electronic government of the Republic of Kazakhstan. 
level is lacking and requires further research.

However, Kazakhstan still struggles with corruption in public administration that hinders efficiency and quality of public services. Politicians and administrative government executives didn't want to participate and help with the integration of online systems (Bhuiyan, 2010; Janenova, 2010). They knew that such systems will decrease their importance, they will lose their power, status and all the illegal payments that they receive due to the corrupted governmental system. For instance, it took 8 years to persuade the Traffic Police to create e-services for issuance of driving licenses - which, in traditional offline form, was considered to be a highly corrupted service.

Kazakhstan was ranked 123rd globally in Corruption Perception Index in 2015 (Transparency International, 2015). According to the latest survey, e-government activities in Kazakhstan are assessed positively by citizens for its impact on the reduction of administrative barriers and corruption (Sheryazdanova et al., 2016)

Thus, scholars believe that e-government in Kazakhstan can helps to reduce corruption and brings more accountability in public service (Sheryazdanova et al., 2016). However, implementation of services such as Citizen Service Centers cannot automatically fix deficiencies in the work of public sector. The policies and approaches that work in developed countries should be critically analyzed and considered before they are implemented in transitional countries such as Kazakhstan (Janenova and Kim, 2016).

Digital public services in rural areas in Kazakhstan

In Kazakhstan, there are 14 provinces and 3 cities and more than $52 \%$ of population lived in urban areas (CIA, 2016). Kazakhstani government has introduced a way of combined public service delivery via Integrated System for Citizen Service Centers that was established in 2007. The centers are operated by the state company "Government for Citizens" that was established in 2016. The system provides a nation-wide network of one stop shops around Kazakhstan and serves as an offline "alternative delivery" of services for citizens (Janenova, 2010; Janenova and Kim, 2016). Currently the centers are present in 16 cities around Kazakhstan. To serve people in remote settlements, there also mobile Citizen Service Centers operating around the country. In total the branches operate at 270 places in Kazakhstan. At the Center, citizens can ask for assistance in 8 life events such as licensing and permits, migration and archives, real estate, registration and business development, family and education, social security and employment, transport and communications and tourism and sports (Government for Citizens, 2016).

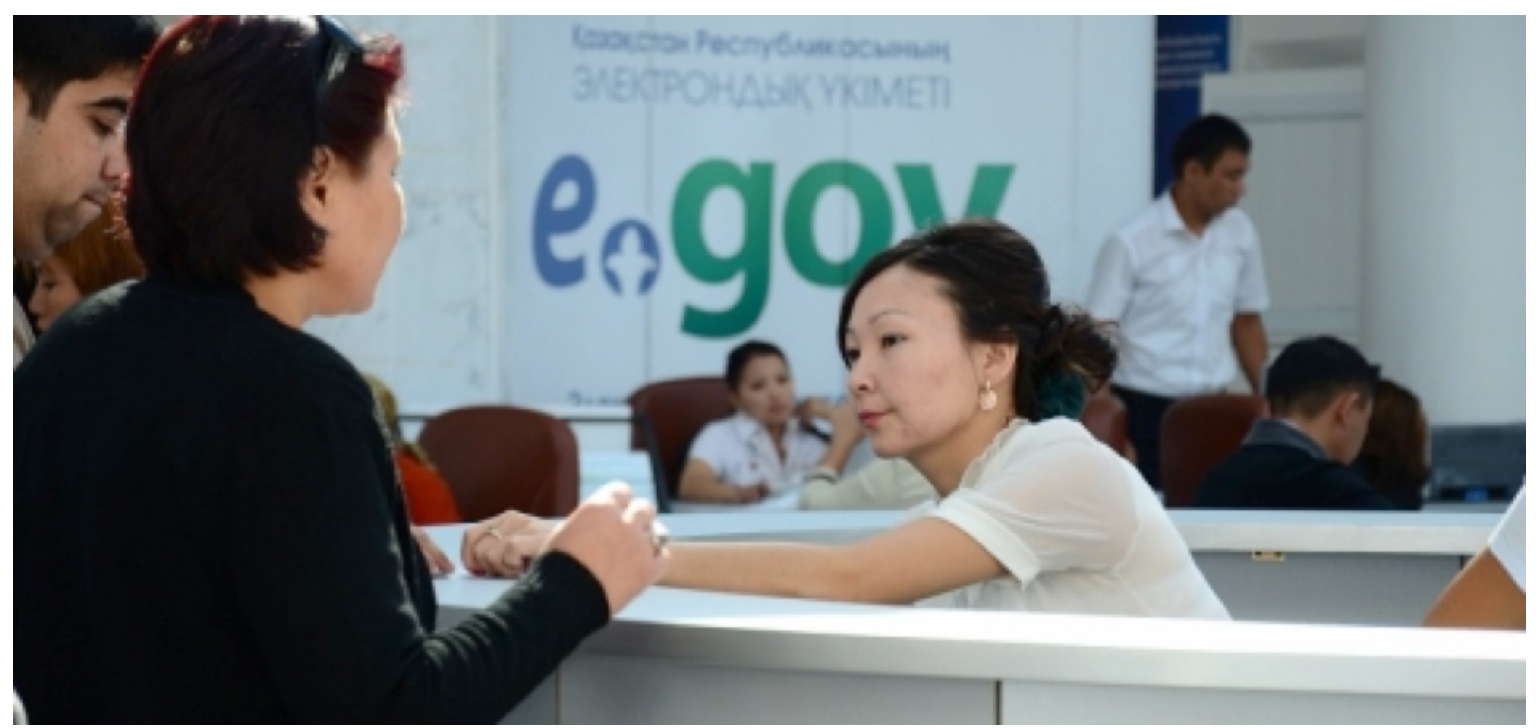

Source: http://kzregdev.kz/content/representatives-european-union-oss

Figure 3: Citizen Service Center in Kyzylorda, Kazakhstan. 


\section{Conclusion}

The paper presented multiple points of view on digital public services provided by governments in the Czech Republic and Kazakhstan addressing the question whether or not digital public services matter. Our answer to the question is: 'Yes, digital public services matter'. However, the implementation, provision and local conditions may lead to very different results, as we reflected in the comparative study.

The aim of the paper was to compare e-government between two countries from and outside the EU. Regarding the first research question, we can confirm that a country from outside the EU (Kazakhstan) can provide better organized supply of digital services than an EU member state (Czech Republic) at least on the national level. Even if the provision is good on the supply side, the other side of the coin - satisfaction of the real users has to be examined as well. In this respect, the most advanced measurement of digital public services from the user's perspective has been provided by DESI so far. We propose that similar benchmarking of digital public services should be conducted in several countries outside of the EU to provide comparable data.

To address the second research question, we conducted thorough literature review of global e-government surveys, which provided interesting facts about remarkable performance of digital public services in a transitional country such as Kazakhstan that was higher than services in a developed economy such as the Czech Republic. On the other hand, mere comparison of e-government indicators provided by respective surveys does not show a rich picture and the whole context in which e-government and digital public services are operated. The issues such as digital literacy, access to the Internet, multilingualism and corruption significantly influence any digital service provision.

European DESI data has also revealed significant discrepancies among national, regional and local services in the Czech Republic. In Kazakhstan, a survey on quality of local e-services is lacking. For rural development, the survey should consider differences in rural areas and their communities.

\section{Acknowledgements}

The results and knowledge included herein have been obtained owing to support from the Internal grant agency of the Faculty of Economics and Management, Czech University of Life Sciences in Prague, grant no. 20161028, "Assessment of quality, usability and accessibility of electronic services from the perspective of small and middle sized enterprises in the agrarian sector ".

Corresponding author:

Ing. Miloš Ulman, Ph.D.

Department of Information Technologies, Faculty of Economics and Management

Czech University of Life Sciences Prague, Kamýcká 129, Prague 6 - Suchdol, 165 21, Czech Republic

Phone: +42022438 2050,E-mail: ulman@pef.czu.cz

\section{References}

[1] Al-Hujran, O., Migdadi, M., Al-Debei, M. M., and Chatfield, A. (2015) "The imperative of influencing citizen attitude toward e-government adoption and use", Computers in Human Behavior, Vol. 53, pp. 189-203. ISSN 07475632. DOI:10.1016/j.chb.2015.06.025.

[2] Ardielli, E. and Halásková, M. (2015) "Assessment of E-government in EU Countries", Scientific Papers of the University of Pardubice. Series D, Faculty of Economics and Administration, Vol. 22, No. 34, pp. 4-16. ISSN 1211555X.

[3] Arendsen, R., Peters, O., ter Hedde, M. and van Dijk, J. (2014) "Does e-government reduce the administrative burden of businesses? An assessment of business-to-government systems usage in the Netherlands", Government Information Quarterly, Vol. 31, No. 1, pp. 160-169. ISSN 0740-624X. DOI:10.1016/j.giq.2013.09.002.

[4] Bhuiyan, S. H. (2010) "E-Government in Kazakhstan: Challenges and its role to development", Public Organization Review, Vol. 10, No. 1, pp. 31-47. ISSN 15667170. DOI:10.1007/s11115-009-0087-6. 
[5] Burden, K. (2016) "EU update", Computer Law and Security Review: The International Journal of Technology Law and Practice, Vol. 32, No. 3, pp. 540-545. ISSN 0267-3649. DOI:10.1016/j.clsr.2016.04.001

[6] CIA. (2016) "The World Factbook 2016-17". Central Intelligence Agency. [Online]. Available: Washington, DC: https://www.cia.gov/library/publications/the-world-factbook/index.html [Accessed: 20 December, 2015].

[7] Czech Statistical Office (2013) “Municipalities of the Czech Republic, 2013”. Czech Statistical Office. [Online]. Available:https:/www.czso.cz/documents/10180/20556813/3202041403.pdf/024611790469-419a-935a-e1b3452884e4?version=1.0 [Accessed: 20 December, 2015].

[8] EC. (2010) "European Interoperability Framework (EIF) for European public services. Annex 2 to the Communication from the Commission to the European Parliament, the Council, the European Economic and Social Committee and the Committee of Regions 'Towards interoperability for European public services", European Commission. [Online]. Available: http://ec.europa.eu/isa/ documents/isa_annex_ii_eif_en.pdf[Accessed: 20 December, 2015].

[9] EC. (2014) "Delivering on the European Advantage? How European Governments can and should benefit from innovative public services"'", European Commission. [Online]. Available: https://ec.europa.eu/digital-single-market/en/news/eu-egovernment-report-2014-shows-usabilityonline-public-services-improving-not-fast [Accessed: 20 December, 2015].

[10] EC. (2015) “Digital Agenda Scoreboard 2015", European Commission. [Online] Available: https://ec.europa.eu/digital-single-market/en/news/digital-agenda-scoreboard-2015-most-targetsreached-time-has-come-lift-digital-borders. [Accessed: 20 December, 2015].

[11] EC. (2016a) "DESI 2016 Digital Economy and Society Index. Methodological note", European Commission. [Online]. Available: https:/ec.europa.eu/digital-single-market/en/desi [Accessed: 15 December, 2015].

[12] EC. (2016b) "Europe's Digital Progress Report (EDPR) 2016. Czech Republic". European Commission. [Online]. Available: https://ec.europa.eu/digital-single-market/en/downloadscoreboard-reports [Accessed: 15 December, 2015].

[13] EIU. (2013) "E-government in Europe, the Middle East and Africa. Expert views on the UN e-government survey". Economist Intelligence Unit. [Online]. Available: workspace.unpan.org/ sites/Internet/.../Expert_views_egov_surveyEMEA_EIU.pdf [Accessed: 20 December, 2015].

[14] Eurostat. (2014) "Statistics on enterprises" [Online]. Available: http://ec.europa.eu [Accessed: 15 December, 2015]

[15] Fan, J. and Yang, W. (2015) "Study on E-Government services quality: The integration of online and offline services", Journal of Industrial Engineering and Management, Vol. 8, No.3, pp. 693-718. ISSN 20130953. DOI:10.3926/jiem.1405.

[16] Gilbert, E., Karahalios, K. and Sandvig, C. (2010) "The network in the garden: Designing social media for rural life”, American Behavioral Scientist, Vol. 53, No. 9, pp. 1367-1388. ISSN 00027642. DOI: $10.1177 / 0002764210361690$.

[17] Government for Citizens (2016) “Citizen Service Center” [Online]. Available: http://www.con.gov. kz/ [Accessed: 15 December, 2015]

[18] IMF. (2015) "World Economic Outlook Database". International Monetary Fund. [Online]. Available: http://www.imf.org/external/pubs/ft/weo/2015/02/weodata/index.aspx [Accessed: 15 December, 2015]

[19] Interfax. (2015) "Kazakhstan E-gov provides services to 3.5 million registered users", Kazakhstan General Newswire.

[20] ITU. (2015) "Measuring the information society report", International Telecommunication Union Geneva. ISBN 978-92-61-15791-3. 
[21] Janenova, S. (2010) "E-Government in Kazakhstan: Challenges for a transitional country", Paper presented at the $18^{\text {th }}$ NISPAcee Annual Conference "Public Administration in Times of Crisis" in Warsaw, Poland.

[22] Janenova, S. and Kim, P. S. (2016) "Innovating Public Service Delivery in Transitional Countries: The Case of One Stop Shops in Kazakhstan", International Journal of Public Administration, Vol. 39, No. 4, pp. 323-333. ISSN 01900692. DOI: 10.1080/01900692.2015.1064445.

[23] Jones, S., Irani, Z. and Sharif, A. (2007) "E-government evaluation: Reflections on three organisational case studies", 40 ${ }^{\text {th }}$ Annual Hawaii International Conference on System Sciences 2007, HICSS'07. ISSN 15301605. DOI: 10.1109/HICSS.2007.189.

[24] Khalil Moghaddam, B. and Khatoon-Abadi, A. (2013) "Factors affecting ICT adoption among rural users: A case study of ICT Center in Iran", Telecommunications Policy, Vol. 37, No. 11, pp. 1083-1094. ISSN 0308596. DOI: 10.1016/j.telpol.2013.02.005.

[25] Kirkman, G. S., Cornelius, P. K., Sachs, J. D., Schwab, K. and World Economic, F. (2002) "Global information technology report 2001 - 2002: readiness for the networked world", New York. ISBN 0195152581.

[26] Kunstelj, M. and Vintar, M. (2004) "Evaluating the progress of e-government development: A critical analysis", Information Polity: The International Journal of Government and Democracy in the Information Age, Vol. 9, No. 3-4, pp. 131-148. ISSN 15701255.

[27] Lijuan, H., Chunfang, Z., Wenjun, Y. and Qiaoqiao, L. (2014) Evolutionary analysis of e-government platform based on the integration of urban and rural areas. EEA - Electrotehnica, Electronica, Automatica, Vol. 62, No. 3, pp. 143-153. ISSN 15825175.

[28] Limba, T. and Gulevičiūtè, G. (2013) "Pecularities of Electronic Public Services Implementation in European Union and Lithuania", Social Technologies / Socialines Technologijos, Vol. 3, No. 2, pp. 372-389. ISSN 2029-7564.

[29] Lindgren, I. and Jansson, G. (2013) "Electronic services in the public sector: A conceptual framework", Government Information Quarterly, Vol. 30, No. 2, pp. 163-172. ISSN 0740-624X. DOI:10.1016/j.giq.2012.10.005.

[30] Mateus, A. (2016) "DESI / I-DESI Digital Economy and Society Index" [Online]. Available: http://unctad.org/meetings/en/Presentation/dtl_eweek2016_AMateus_en.pdf 15 December, 2015]

[31] Máchová, R. (2015) “An Analytical Hierarchy Process Model For The Evaluation of the E-government Development”, Scientific Papers of the University of Pardubice. Series D, Faculty of Economics and Administration, Vol. 22, No. 34, pp. 88-100. ISSN 1211555X.

[32] Miah, S. J. (2012) "The role of end user in e-government application development: A conceptual model in the agricultural context", Journal of Organizational and End User Computing, Vol. 24, No. 3, pp. 69-85. ISSN 15462234. DOI: 10.4018/joeuc.2012070104.

[33] MOIA (2016) "Czech Point, 2016". Ministry of Interior Affairs. [Online]. Available: http://www.czechpoint.cz/web/?q=node/488 aspx [Accessed: 15 December, 2015].

[34] Nayak, S. K., Thorat, S. B. and Kalyankar, N. V. (2010) "Reaching the Unreached A Role of ICT in Sustainable Rural Development", International Journal of Computer Science and Information Security, IJCSIS, Vol. 7, No. 1, pp. 220-224. ISSN 19475500.

[35] Ntaliani, M., Costopoulou, C., Karetsos, S. and Molhanec, M. (2015) Citizen e-Empowerment in Greek and Czech municipalities. $6^{\text {th }}$ International Conference on e-Democracy, e-Democracy 2015; Athens; Greece; 10 December 2015. Vol. 570. ISBN 978-331927163-7. DOI: 10.1007/978-3-319-27164-4_9.

[36] OECD. (2014) "OECD Science, Technology and Industry Outlook 2014". Organisation for EconomicCo-operation and Development. ISBN 978-92-64-22228-1. DOI: $10.1787 / 139 a 90 c 6-e n$. 
[37] Reddick, C. G. and Roy, J. (2013) "Business perceptions and satisfaction with e-government: Findings from a Canadian survey", Government Information Quarterly, Vol. 30, No. 1, pp. 1-9. ISSN 0740-624X. DOI:10.1016/j.giq.2012.06.009

[38] Rorissa, A., Demissie, D. and Pardo, T. (2011) "Benchmarking e-Government: A comparison of frameworks for computing e-Government index and ranking", Government Information Quarterly, Vol. 28, No. 3, pp. 354-362. ISSN: 0740-624X. DOI:10.1016/j.giq.2010.09.006.

[39] Sheryazdanova, G. R., Abdina, A. K., Abdildina, H. S., Kakimzhanova, M. K., Sadykova, T. M., and Gappasova, A. G. (2016) "Development of electronic government in Kazakhstan as a tool to combat corruption", Indian Journal of Science and Technology, Vol. 9, No. 5, pp. 1-7. ISSN 09745645. DOI: 10.17485/ijst/2016/v9i5/87617.

[40] Skersys, T., Butleris, R., Nemuraite, L., Suomi, R., Boer, Y. v. d., Pieterson, W. and Arendsen, R. (2011) "Channel choice in the G2B context: towards a research agenda" $11^{\text {th }}$ IFIP WG 6.11 Conference on e-Business, e-Services, and e-Society, I3E 2011, October 12-14, 2011, Kaunas, Lithuania, pp. 14-27.

[41] Sorrentino, M., De Marco, M. and Depaoli, P. (2015) "Steering the digital agenda at arm's length. All wobble, no spin: The contextual lens", Lecture Notes in Computer Science, Vol. 9248, pp. 31-43. ISBN 9783319224787. DOI: 10.1007/978-3-319-22479-4_3.

[42] Sá, F., Rocha, Á. and Pérez Cota, M. (2015) "From the quality of traditional services to the quality of local e-Government online services: A literature review", Government Information Quarterly, Vol. 33, No. 1. ISSN 0740-624X. DOI:10.1016/j.giq.2015.07.004.

[43] Tan, C. W., Benbasat, I. and Cenfetelli, R. T. (2013) "IT-Mediated Customer Service Content and Delivery in Electronic Governments: An Empirical Investigation of the Antecedents of Service Quality". MIS Quarterly, Vol. 37, No. 1, pp. 77-109. ISSN 02767783.

[44] Townsend, L., Fairhurst, G., Wallace, C. and Sathiaseelan, A. (2013) "Enhanced broadband access as a solution to the social and economic problems of the rural digital divide", Local Economy, Vol. 28, No. 6, pp. 580-595. ISSN 02690942. DOI: 10.1177/0269094213496974.

[45] Transparency International. (2015) "Corruption Perceptions Index 2015" [Online]. Available: http://www.transparency.org/cpi2015 [Accessed: 25 December 2015].

[46] UN. (2014) "UN E-Government Survey 2014. E-Government for the Future We Want", United Nations, New York. ISBN 978-92-1-123198-4.

[47] Vanek, J., Cervenkova, E., Jarolimek, J. and Simek, P. (2010) "State and evaluation of information and communication technologies development in agricultural enterprises in the Czech Republic", Plant Soil and Environment, Vol. 56, No. 3, pp. 144-147. ISSN 12141178.

[48] World Bank. (2016a) "Country and Lending Groups". The World Bank. [Online]. Available: http://data.worldbank.org/about/country-and-lending-groups - Upper_middle_income [Accessed: 12 January 2016].

[49] WEF. (2015) "The global Information technology report 2015: ICTs for inclusive growth". World Economic Forum, Geneva. ISBN 978-92-95044-48-7.

[50] World Bank. (2016b) "Doing Business 2016", The World Bank. ISBN 978-1-4648-0668-1. DOI: $10.1596 / 978-1-4648-0667-4$.

[51] Xia, J. (2010) "Linking ICTs to rural development: China's rural information policy", Government Information Quarterly, Vol. 27, No. 2, pp. 187-195. ISSN 0740624X. DOI: 10.1016/j.giq.2009.10.005. 